\title{
NDT and SHM for fatigue and fracture mechanical property determination
}

\section{NDT i SHM w ocenie właściwości zmęczeniowych i pęknięć}

\section{Abstract}

Plant components in power plants like nuclear power plants (NPP) and chemical plants like refineries are very often manufactured in austenitic stainless steel because of the resistance of the material against corrosion. However, the components are very often under elevated service temperatures in the $280^{\circ} \div 300^{\circ} \mathrm{C}$ regime and under mechanical cyclic deformation. The components - so far designed with sufficient fracture toughness - fail by fatigue crack initiation, crack growth to local leak and normally not break.

When the cyclic deformation is in the LCF (low-cyclefatigue, some thousand load cycles till end of life) regime the cracking is due surface-breaking cracks. NDT technology most applied is MT, i.e. magnetic testing as magnetic particle inspection based on the magnetic leakage fields of the surface cracks. So far the components are not ferromagnetic; PT (penetrant testing) is well introduced. In the nuclear field, because of the reason of contamination of the inspection media very often in the last years eddy current inspection (ET) was introduced and qualified.

However, worldwide there is the strategy to life extent the nuclear power plants, and therefore in the last decade R\&D to NDT for nuclear safety has concentrated to develop material characterization techniques for early detection of ageing phenomena [1]. The objective is to detect and quantify ageing in the material microstructure before a macroscopic crack occurs.

These techniques were applied to monitor the fatigue behavior in the laboratory at servo-hydraulic machines. The next step is planned to implement the technology into lifetime management strategies of NPP to monitor components, i.e. pipes like the surge line or spray lines.

The developed techniques also have a high potential to monitor fracture mechanical tests which normally are very time-consuming. First approaches are discussed in the here presented contribution. By using UT and time-of-flight of the surface-acoustic wave (Rayleigh wave) the crack-initiation at a fracture mechanical test specimen can be detected.

\section{Streszczenie}

Elementy elektrowni jądrowych i fabryk chemicznych, $\mathrm{np}$. rafinerii, są wykonywane $\mathrm{z}$ wysokostopowych stali austenitycznych ze względu na dużą odporność na korozję. Jednak elementy często pracują $w$ temperaturze powyżej dopuszczalnej wynoszącej $280 \div 300^{\circ} \mathrm{C}$ i poddawane są cyklicznym deformacjom. Elementy zaprojektowane tak by, miały odpowiednią odporność na pęknięcia, ulegają zniszczeniu w wyniku rozwoju lokalnej wady. W przypadku gdy cykliczne deformacje znajdują się w przedziale LCF (małe cykliczne zmęczenia, wynoszące kilka tysięcy cykli w całym okresie pracy), nie występują groźne złamania. Ze względu na to, że stal austenityczna nie jest ferromagnetyczna, nie jest możliwe wykorzystanie metody strumienia rozproszonego. Do wykrywania wad powierzchniowych używana jest metoda penetracyjna. W elektrowniach jądrowych używana jest metoda prądów wirowych. Obecnie podejmowane są wysiłki mające na celu wydłużenie czasu pracy elektrowni jądrowych. $Z$ tego powodu rozwijane są metody wczesnego wykrywania starzenia się materiału [1]. Celem jest wykrycie i ilościowa ocena starzenia przed powstaniem wady. Umożliwiają one wczesną ocenę stopnia starzenia się materiału. W pierwszym kroku te metody są używane w laboratorium. Następnie zostaną one wykorzystane w badaniach przemysłowych, w szczególności w badaniu starzenia się rurociągów. Rozwijane metody są bardzo użyteczne w testowaniu pęknięć, bez użycia ich proces jest bardzo czasochłonny. W obecnej pracy jest opisana faza laboratoryjna. Posługując się metodą ultradźwiękową, można wykryć wadę we wczesnej fazie. Metoda powinna być testowana i oceniana ilościowo. Czas testowania zostanie wyraźnie skrócony. Przewiduje się dalsze badania. Obecnie w tym celu używany jest specjalnie skonstruowany tester ultradźwiękowy EMAT.

Gerd Dobmann - Fraunhofer-IZFP, Saarbrücken. 


\section{Introduction}

Plant components in power plants like nuclear power plants (NPP) and chemical plants like refineries are very often manufactured in austenitic stainless steel because of the resistance of the material against corrosion. However, the components are very often under elevated service temperatures in the $280 \div 300^{\circ} \mathrm{C}$ regime and under mechanical cyclic deformation. The components - so far designed with sufficient fracture toughness - fail by fatigue crack initiation, crack growth to local leak and normally not break.

When the cyclic deformation is in the LCF (low-cycle-fatigue, some thousand load cycles till end of life) regime the cracking is due surface-breaking cracks. NDT applied in service inspection trials is the measure to early detect cracking and then to reliably plan and organize repair. NDT technology most applied is MT, i.e. magnetic testing as magnetic particle inspection based on the magnetic leakage fields of the surface cracks. So far the components are not ferromagnetic; PT (penetrant testing) is well introduced. In the nuclear field, because of the reason of contamination of the inspection media very often in the last years eddy current inspection (ET) was introduced and qualified.

However, worldwide there is the strategy to life extent the nuclear power plants, for instance to a safe life time of 80 years, and therefore in the last decade R\&D to NDT for nuclear safety has concentrated to develop material characterization techniques for early detection of ageing phenomena [1]. The objective is to detect and quantify ageing in the material microstructure before a macroscopic crack occurs.

Fraunhofer-IZFP in charge of the German Ministry of Economy and Technology was strongly engaged in the Nuclear Safety Research Program and some new approaches based on micromagnetic, electromagnetic, and ultrasonic techniques are now available to characterize fatigue and other ageing phenomena. In a first approach these techniques were applied to monitor the fatigue behaviour in the laboratory at servo-hydraulic machines. The next step is planned to implement the technology into lifetime management strategies of NPP to monitor components, i.e. pipes like the surge line or spray lines.
The developed techniques also have a high potential to monitor fracture mechanical tests which normally are very time-consuming. First approaches are discussed in the here presented contribution. By using UT and time-of-flight of the surface-acoustic wave (Rayleigh wave) the crack-initiation at a fracture mechanical test specimen can be detected. However, statistically the approach has to be verified and qualified. So far this will be possible; the testing time can be extremely shortened in the future. Further projects are going on. Important in general is the fact that special sensors are applied for UT, the so-called EMAT.

EMAT (electromagnetic acoustic transducer) have the advantage to be used also at elevated temperatures as they do not need coupling media [2, 3].

\section{Materials}

Austenitic metastable steels of the grades AISI 321 (German grade 1.4541 - Ti-stabilized) and AISI 347 German grade 1.4550 - Nb-stabilized) are often used in power station and plant constructions so also in German NPP. Metastable austenitic steel forms ferromagnetic $\alpha$ ' martensite due to quasi-static and cyclic loading. This presupposes the exceeding of a threshold value of accumulated plastic strain. The amount of martensite as well as its magnetic properties should provide information about the fatigue damage. Fatigue experiments were carried out at different stress and strain levels at room temperature (RT) and at $\mathrm{T}=300^{\circ} \mathrm{C}[4,5]$. Table I. and Table II. show the chemical compositions.

The $\mathrm{Nb}$-stabilized material obviously has a higher $\mathrm{Nb}$ and $\mathrm{Ni}$ content compared with the Ti and $\mathrm{Ni}$ content of the 1.4541 material. That was primarily introduced into the specification in order to reduce the sensitivity for sensitization during heat treatments, i.e. to reduce the risk for inter-granular stress corrosion cracking. A secondary effect is that the material is only prone to show a phase transformation to a' martensite when fatigued at RT.

Sufficient amounts of mechanical energy due to plastic deformation lead to this phase transformation

Table I. Material X6 CrNiTi1810 (German material No. 1.4541), 2 heats (in mass \%)

Tablica I. Materiał X6 CrNiTi1810 (materiał niemiecki nr 1.4541), 2 wytopy (w \% masy)

\begin{tabular}{|c|c|c|c|c|c|c|c|c|c|c|}
\hline Elements & $\mathrm{C}$ & $\mathrm{N}$ & $\mathrm{Si}$ & $\mathrm{Mn}$ & $\mathrm{P}$ & $\mathrm{S}$ & $\mathrm{Cr}$ & $\mathrm{Mo}$ & $\mathrm{Ni}$ & $\mathrm{Ti}$ \\
\hline Heat F & 0,04 & - & 0,44 & 1,14 & 0,033 & 0,004 & 17,74 & - & 9,3 & 0,35 \\
\hline Producer specification & 0,05 & 0,002 & 0,4 & 1,09 & 0,024 & 0,005 & 17,81 & 0,27 & 9,3 & 0,3 \\
\hline Heat F & 0,025 & & 0,44 & 1,76 & 0,026 & 0,02 & 17,15 & & 9,83 & 0,16 \\
\hline WWK [2] & 0,03 & 0,006 & 0,45 & 1,72 & 0,022 & 0,0014 & 17,31 & 0,28 & 10,18 & 0,16 \\
\hline
\end{tabular}


Table II. X6 CrNiNb 1810 (German material No. 1.4550), (in mass \%) [6]

Tablica II. X6 CrNiNb 1810 (materiał niemiecki nr. 1.4550), (w \% masy) [6]

\begin{tabular}{|c|c|c|c|c|c|c|c|c|c|}
\hline $\mathrm{C}$ & $\mathrm{Cr}$ & $\mathrm{Ni}$ & $\mathrm{Nb}$ & $\mathrm{N}$ & $\mathrm{Si}$ & $\mathrm{Mn}$ & $\mathrm{P}$ & $\mathrm{S}$ & $\mathrm{Al}$ \\
\hline 0,040 & 17,600 & 10,640 & 0,620 & 0,007 & 0,410 & 1,830 & 0,020 & 0,007 & 0,016 \\
\hline $\mathrm{Ti}$ & $\mathrm{Sn}$ & $\mathrm{Mo}$ & $\mathrm{W}$ & $\mathrm{Cu}$ & $\mathrm{Co}$ & $\mathrm{V}$ & $\mathrm{Pb}$ & $\mathrm{B}$ & $\mathrm{Fe}$ \\
\hline 0,020 & 0,008 & 0,290 & 0,030 & 0,060 & 0,010 & 0,070 & $<0,008$ & $<0,005$ & $\mathrm{Rest}$ \\
\hline
\end{tabular}

from fcc austenite without diffusion to tetragonal or bcc ferromagnetic $\alpha$-martensite. As the martensitic volume fractions in the case of 1.4541 are especially low for service-temperatures of about $300^{\circ} \mathrm{C}[4,5]$ highly sensitive measuring systems are necessary.

Besides systems on the basis of a HTC-SQUID (High Temperature Super Conducting Quantum Interference Device) special emphasis was on the use of GMR-sensors (giant magnetoresistors) which have the strong advantage to be sensitive for dc-magnetic fields too without any need for cooling [7]. In combination with an eddy-current transmitting coil anduniversal eddy-current equipment as receiver hardware the GMR-sensors were used especially to on-line monitoring the fatigue experiments in the servo-hydraulic fatigue machine [8].

\section{LCF at room temperature (RT) and at $300^{\circ} \mathrm{C}$}

When performing a multiple-step loading experiment (stress controlled, mean stress free $R_{\sigma}=-1$ ) as shown in Fig. 1., according to a loading time function as shown in red color the eddy current impedance (blue color) of the GMR sensor exactly follows this functional behaviour. In other words, the impedance curve is a one-to-one image of the loading history but in addition a certain off-set is observed revealing the occurrence of $\alpha^{\prime}$ martensite which is enhancing the magnetism of the specimen when fatigued in the geomagnetic field.

The electromagnetic properties discussed for characterization at RT cannot be sensed at elevated temperatures and cooling of sensors cannot be accepted at real components in practice. Therefore the need for a new measurement technology was given. This is based on the use of electromagnetic acoustic transducers (EMAT). An EMAT is - in its simplest version - no more than a spiral inductive coil in which a high-frequency tone-burst (a couple of sine-periods) is excited by a pulse generator [2,3]. The coil induces eddy currents in the conductive material of which the magnetic field of a permanent magnet $(\mathrm{NdFeB})$ in normal direction is superimposed. The magnetic induction is perpendicular to the tangential direction of the eddy currents and the mechanical Lorentz forces are the cross vector product of both, i.e. radially oriented, exciting radially polarized

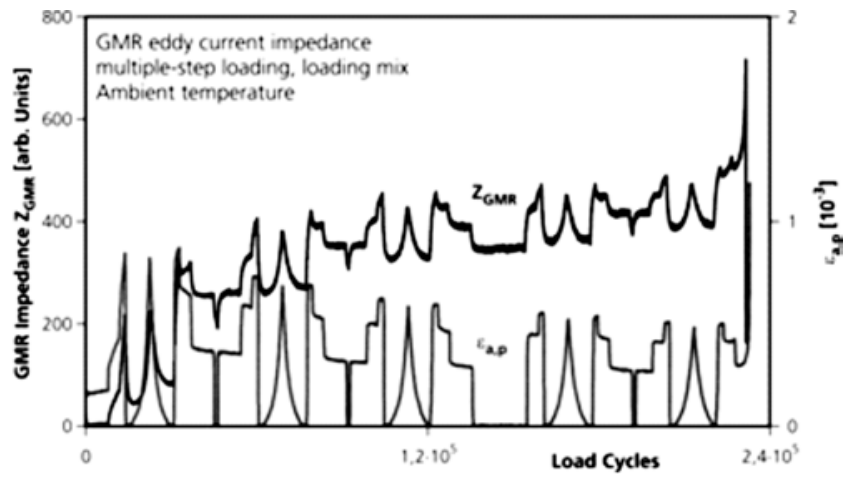

Fig. 1. Multiple-step loading at RT (material according to Table I, Tistabilized), the accumulated plastic strain $\varepsilon_{\text {ap }}$ and the GMR-transfer impedance $Z_{\mathrm{GMR}}$ versus load cycle number

Rys. 1. Sumaryczne odkształcenie plastyczne $\varepsilon_{\mathrm{ap}}$ oraz impedancja $Z_{G M R}$ przeniesienia GMR w odniesieniu do ilości cykli podczas wykonywania eksperymentu w RT (materiał zgodny z Tablicą I, stabilizowany Ti),

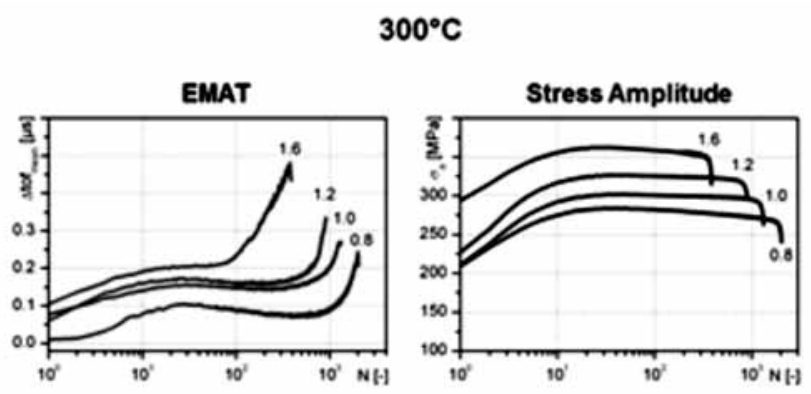

Fig. 2. LCF at $300^{\circ} \mathrm{C}$ (material according to Table II, Nb stabilized), the mean time-of-flight and the stress amplitude versus load cycle number Rys. 2. LCF przy $300^{\circ} \mathrm{C}$ (materiał zgodny z Tablicą II, stabilizowany $\mathrm{Nb}$ ), średni czas cząstki oraz amplituda naprężeń w odniesieniu do ilości cykli

shear waves propagating in axial direction. Transmitter and receiver EMAT were built in the clamping devices of the servo hydraulic machine. In the A-scan the timeof-flight (tof) of the through-transmitted ultrasonic shear wave and its amplitude is measured. As the tof during one load cycle varies between the smallest value (smallest elongation) and largest value (largest elongation) the tofmean-value is calculated (arithmetic mean) as a characteristic damage parameter as function of the load cycles.

Fig. 2. compares in case of the full strain range $0.8 \leq \varepsilon_{\text {at }} \leq 1.6 \%$ the curves of tofmean obtained at $300^{\circ} \mathrm{C}$ with the cyclic deformation curves ( $\sigma$ as function of load cycles). Whereas, the stress curves show no influence of a continuously increasing damage parameter because of this nearly constant behavior (first strain 
ageing then saturation or slight cyclic softening before failure) along the full life time, the tofmean curves show a strong monotonic increasing during the last third of life and indicate therefore very early elapsing of life. That is mainly due to the fact that micro-cracking in the specimen surface is sensed.

\section{Single - edge bending test}

SE(B) (Single-Edge Bending) samples were machined out of a large block of the material 22NiMoCr3-7, a German bainitic martensitic pressure-vessel-material. At room temperature, this steel grade is known to show ductile behaviour under quasi-static load conditions. Fig. 3 shows a drawing of the sample geometry. All samples were prepared with an initial fatigue crack (crack starter).

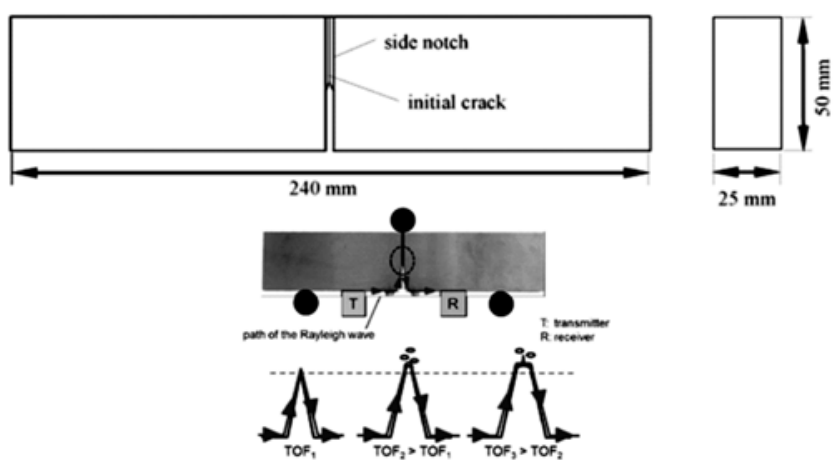

Three-point bending experiments according to the standards described in ESIS P2-92, ASTM E 399, $E 1737$ and $E 1820$ were performed using these samples [9-13] by the Materials Testing Institute, University of Stuttgart. The standard experiment involves the insitu measurement of the applied load, the load point travel and the crack opening displacement (COD) by using clip gauges. After the experiment, the sample is broken apart, the crack elongation is measured in the microscope, and only by using this information, the $\mathrm{J}$ integral is computed in order to determine crack resistance i.e. toughness parameters.

As an approach to in-situ and on-line determine the crack growth during the experiment, the time of flight of an ultrasonic surface wave which travels around the crack was analysed by Fraunhofer-IZFP. A pair of EMAT (transmitter T, receiver $R$ ) was used to excite and to receive this Rayleigh wave in pitch-andcatch-technique. The crack growth was expected to increase the travelling distance of the Rayleigh wave which should result in an increased TOF. Throughout the approximately $2 \frac{1}{2}$ hours of each three-pointbending experiment with partial load relief cycles, the machine data (load force, crack-opening-displacement (COD)) were recorded along with the time-offlight data; corresponding crack-growth data were determined in the microscope after the test on the broken specimen surface. A linear correlation to the measured time-of-flight data was obtained. In the online measured to f-curve a typical turning point is detected indicating crack-initiation (Fig. 4).

Fig. 3. Approximate $S B(B)$ sample geometry and sketch for crackpropagation measurement by surface-acoustic Rayleigh-wave Rys. 3. Geometria $\mathrm{SB}(\mathrm{B})$ próbki oraz rysunek pomiaru rozchodzenia się pęknięć na powierzchni na bazie powierzchniowej fali akustycznej Rayleigha
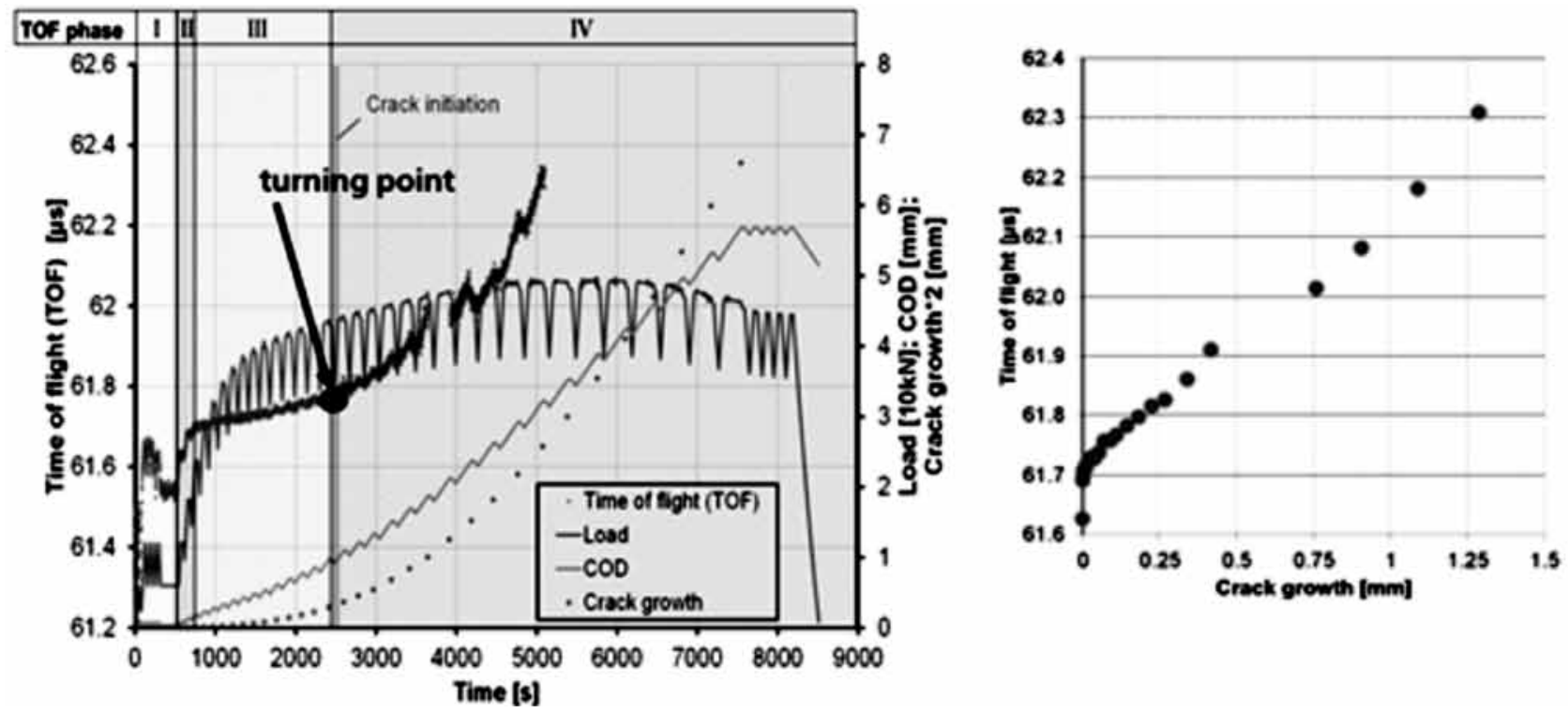

Fig. 4. On-line monitoring result, tof in blue, COD in green. The crack growth in red dots is not online determined (microscopy evaluation after failure of the specimen; on the right tof versus crack growth

Rys. 4. Wyniki monitoringu online, cząsteczki, TOF jest oznaczony na niebiesko, COD (krytyczne rozwarcie pęknięcia) na zielono. Przyrost pęknięcia oznaczony czerwonymi kropkami nie został określony online - ocena mikroskopowa po zniszczeniu próbki; po prawej czas cząsteczki w odniesieniu do przyrostu pęknięcia 


\title{
Conclusions
}

By use of non-destructive techniques the ability was demonstrated to characterize materials ageing due to fatigue:

- at RT by eddy current excitation of the measuring length of the fatigue specimen and GMR-transferimpedance measurement during LCF of austenitic stainless steel when martensitic phase transformation is observed;

- at $300^{\circ} \mathrm{C}$ by time-of-flight measurement of an ultrasonic shear wave pulse propagating between transmitter- and receiver-EMAT built in the clamping devices of the fatigue specimen.

- time-of-flight measurements (tof) of a Rayleigh wave transmitted and received by EMAT was also used to on-line-monitor crack-growth during the fracture mechanical SE(B) bending test. Crack initiation is especially indicated and tof increases linearly with crack growth.

\section{Literature}

[1] G. Dobmann: Non-destructive Testing for Ageing Management of Nuclear Components, Nuclear Power - Control, Reliability and Human Factors, 2011, ISBN: 978-953-307-599-0

[2] H.-J. Salzburger: EMATs and its Potential for Modern NDE State of the Art and Latest Applications, Proceedings of the IEEE International Ultrasonics Symposium 1, 2009, 621-628

[3] H.-J. Salzburger, F. Niese, and G. Dobmann: EMAT pipe inspection with guided waves, Welding in the world 56 (2012), 5-6

[4] H.-J. Bassler: Cyclic deformation behavior and strain-induced development of martensite in case of the austenitic stainless steel X 6 CrNiTi 1810 (in German), Ph.D.-thesis at the University Kaiserslautern, 1999

[5] M. Lang: Non-destructive characterization of the cyclic deformation behavior and the development of strain-induced martensite in case of the austenitic stainless steel X6 CrNiTi 1810 by use of sensitive magnetic sensors (in German), Ph.D.thesis at the University of the Saarland, Saarbrücken, 2000

[6] I. Altpeter et al: Early detection of damage in thermo-cyclically loaded austenitic materials, ENDE 2011 proceedings, ISO press, ENDE 2011 conference, March 10-12, Chennai

[7] German patent DE 3820475: Magnetfeldsensor mit ferromagnetischer, dünner Schicht,filed on 16.06.1988
[8] A. Yashan,: To eddy current (EC) and magnetic leakage flux (ET) testing with GMR sensors (in German), Ph.D.thesis at the Saar university, Saarbrücken, 2008

[9] ESIS P2-92, Procedure for determining the fracture toughness of materials, European Structural Integrity Society (1992)

[10]ESIS P6-98, Procedure to measure and calculate material parameters for the local approach to fracture using notched tensile specimens, European Structural Integrity Society. Ed. K.-H. Schwalbe, GKSS Geeshacht (1998)

[11] ASTM E 399-90, Standard test method for plane-strain fracture toughness of metallic materials, Annual Book of ASTM Standards Vol. 03.01, American Society for Testing and Materials (1997)

[12]ASTM E 1737-96, Standard test method for J-integral characterization of fracture toughness, Annual Book of ASTM Standards Vol. 03.01, American Society for Testing and Materials (1997)

[13]ASTM E 1820-96, Standard test method for measurement of fracture toughness, Annual Book of ASTM Standards Vol. 03.01, American Society for Testing and Materials (1997).

\section{Acknowledgement}

The author very much acknowledge the high valued contribution of colleagues from Fraunhofer-IZFP which are Iris Altpeter, Klaus Szielasko, Ralph Tschuncky, and Gerhard Hübschen. The special thanks are to the Institute of Material Science and Engineering, WKK, (Prof. Dietmar Eifler), Technical University Kaiserslautern and the Materials Testing Institute, MPA, University Stuttgart (Prof. Eberhard Roos) with their teams for the long year fruitful co-operation. Last but not least thank is to the Ministry of Economy and Technology in Germany for the financial support in different projects beginning in 1979 up to now.

\author{
Redakcja Przegląd Spawalnictwa, ul. Świętokrzyska 14a, 00-050 Warszawa \\ tel.: 2282725 42, fax: 2233614 79; e-mail: pspaw@ps.pl, www.pspaw.ps.pl
}

